\title{
The Materiality of Medieval Manuscripts
}

\author{
Henrike Lähnemann \\ St Edmund Hall, University of Oxford
}

The article presents the author's Inaugural Lecture for the Chair in German Medieval Literature and Linguistics, delivered on Thursday 21 January 2016. The subject of the lecture is a new acquisition by the Bodleian Library in Oxford, a psalter written ca. 1500 by the nun Margaret Hopes in the Cistercian convent of Medingen near Lüneburg, MS. Don. e. 248. The hypothesis advanced is that the nuns use the materiality of their prayer-book as the embodiment of their devotion. The psalter is analysed in terms of its physical realisation (material, layout, writing, corrections, music, illustrations, and additions) and its execution interpreted as a spiritual act. The journey of the manuscript beyond the Middle Ages is highlighted through the accommodation of the manuscript to the Lutheran Reformation and the addition of a bone plaque with a floral border in the nineteenth century, reflecting the contemporary concept of the medieval object. The purpose of the lecture is an enquiry into the changing history of manuscripts as objects of devotional, antiquarian and scholarly interest.

Photos of the psalter Oxford, Bodleian Library, MS. Don. e. 248 by Henrike Lähnemann $(1,2,4,5)$ and Laura Light (6), reproduced by permission of the Bodleian Libraries.

Keywords: Materiality of medieval manuscripts, Manuscript illumination and binding, Psalter, Nuns, Late medieval devotional culture, Northern Germany, Cistercian nuns, Lutheran Reformation, Antiquarianism, Bodleian Library

I.

The focus of my discussion is a new acquisition by the Bodleian Library, a psalter from the Cistercian abbey of Medingen, the fourth manuscript from that convent to arrive in Oxford. The psalter joins the Manual for the Medingen Provost and two prayer-books: a mixed LatinLow German one for Easter in the Bodleian and a Latin one dedicated to the apostle Thomas and the patron saint of Medingen, St Maurice, in Keble College. ${ }^{1}$

\footnotetext{
${ }^{1}$ A podcast of the Inaugural Lecture with all the slides is available via the website for Medieval German http://www.mod-langs.ox.ac.uk/medievalgerman. On 21 January 2016, the manuscript was part of the procession, carried in by Bodley's Librarian accompanied by the current Abbess of Medingen, and displayed at the drinks reception in a case below the medallion of Goethe in room 2 of the Taylorian. The four Medingen manuscripts in Oxford are (sorted according to the sigla): O1) Medingen Bodleian Prayer-Book: Oxford, Bodleian Library, MS. Lat. liturg. f. 4; O2) Manual for the Provost: Oxford, Bodleian Library, MS. Lat. liturg. e. 18; O3) Medingen Keble Prayer-Book: Oxford, Keble College, Ms. Nr. 18; O4) Medingen Bodleian Psalter: Oxford, Bodleian Library, MS. Don. e. 248. The four manuscripts were reunited for the first time since the eighteenth century at a Masterclass in the Weston Library on 22 January 2016. All Medingen manuscripts are listed on medingen.seh.ox.ac.uk (accessed 21 January 2016).
} 
The new Bodleian Medingen Psalter, which was given the shelfmark MS. Don. e. 248, ${ }^{2}$ was written and illustrated by Margaret Hopes who entered the convent at the end of the fifteenth century and is listed in 1524 as cantrix, the nun in charge of the musical instruction and responsible for intoning the liturgy of the Hours. ${ }^{3}$ This is, however, not an official liturgical book but her own personal copy of the Psalms with additional prayers. The Psalms were the texts she knew most intimately, chanting the Latin version of them daily. The text provided the nuns with the phrases and metaphors which inspired their own writing in Latin and German. We can catch a glimpse of how the Psalms generated visual images in the pen drawings associated with particular words in the text. The marginal illustration for the beginning of Psalm 18 (Fig. 1 = fol. $43 v-44 r$ ) is particularly revealing in that respect. The hands holding quills are intertwined with the down stroke of the $p$ in 'opera manuum eius' (fol. 43v). In the words of the King James Version 'The heavens declare the glory of God; and the firmament shows his handiwork' (Ps 18:2). ${ }^{4}$ It is thus God himself, ambidextrously writing the world, who is the exemplar for manuscript production. When the nun puts pen to parchment, she emulates the creative act of God.

\footnotetext{
${ }^{2}$ The donation was made possible by the Art Fund, the Friends of the National Libraries, the Friends of the Bodleian and by a collection among staff and students at the University of Connecticut with whom I had worked on the Medingen prayer-books in the Houghton Library at Harvard. Cf. Bodleian Library Friends' Newsletter Summer 2015-Winter 2015/16 p. 2.

${ }^{3}$ Urkundenbuch des Klosters Medingen, ed. by Joachim Homeyer † (Hanover: Verlag Hahnsche Buchhandlung, 2006); charters from 1505 October 8, p. 585, and 1524 [after June 15], p. 642.

${ }^{4}$ The Psalter is quoted from my own transcription; the numbering follows the Vulgate available on vulsearch.sourgeforge.net. English translations of the Psalms are taken from the New King James Version available on biblegateway.com. English translations of other texts are my own. I wish to thank Elizabeth Andersen for polishing the text. I am indebted to Beate Braun-Niehr who in her catalogue entry for the Medingen Psalter in the Staatsbibliothek Preußischer Kulturbesitz Berlin, Ms. theol. lat. oct. 189, provided me with a thorough introduction to the characteristic features of this group of manuscripts: Beate Braun-Niehr, Die theologischen lateinischen Handschriften in Octavo der Staatsbibliothek zu Berlin - Preußischer Kulturbesitz, Teil 2: Ms. theol. lat. oct. 126-189 (forthcoming). Online from manuscripta-mediaevalia.de (search for obj 31101550). Cf. also Beate Braun-Niehr, 'Ein lateinisches Psalterium aus dem Zisterzienserinnenkloster Medingen (Staatsbibliothek zu Berlin - Preußischer Kulturbesitz, Ms. theol. lat. oct. 189)', in: Von Frauenhand. Mittelalterliche Codices aus dem Nonnenkloster Medingen, ed. by Hans-Walter Stork (forthcoming).
} 


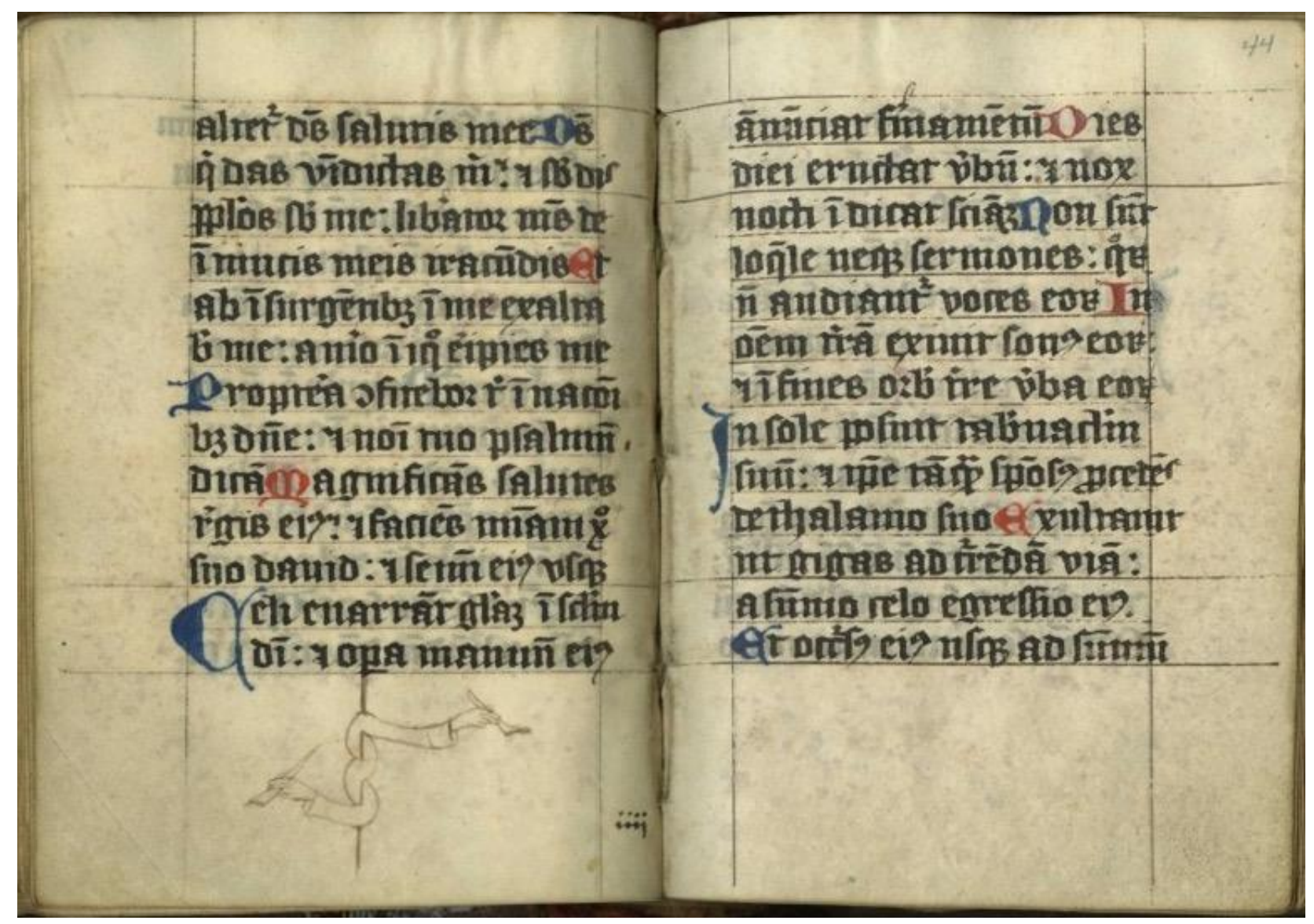

Figure 1: Oxford, Bodleian Library, MS. Don. e. 248, fol. 43v-44r.

The world as book is a topos going back to antiquity, and each period visualises it in terms of its own form of book production. For Margaret Hopes, writing at the very end of the Middle Ages, the world is signified by a traditional manuscript - at that point no longer the default form of text production but all the more symbolic in its materiality. My hypothesis is that it is precisely because of the new significance manuscripts acquired as the art of printing developed that the Medingen nuns emphasised the material side of their text production. The Bodleian Medingen Psalter is a perfect example of this. This starts with the use of precious parchment instead of paper. 


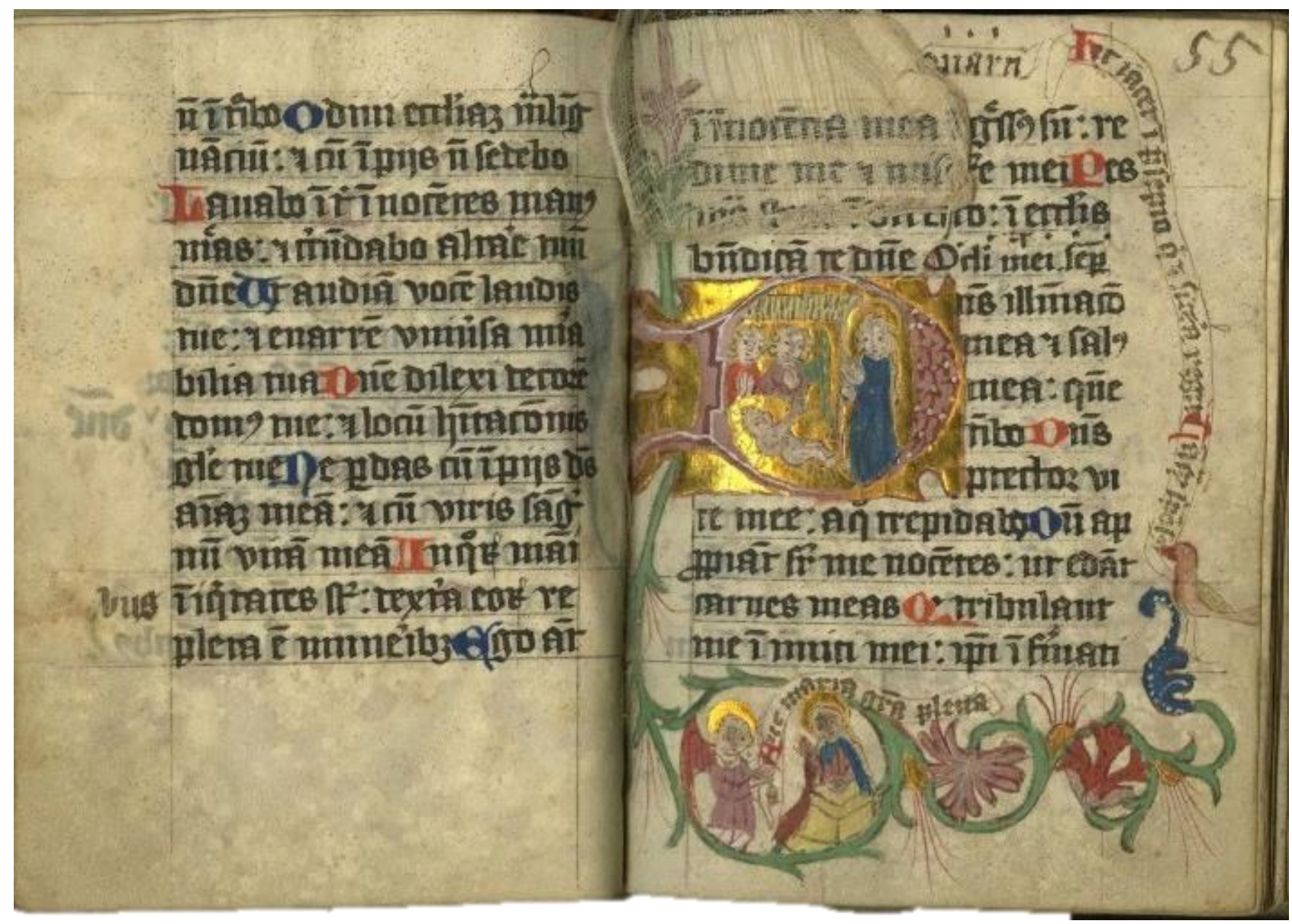

Figure 2: Oxford, Bodleian Library, MS. Don. e. 248, fol. 54v-55r.

The opening of Psalm 26 (Fig. 2 = fol. 54v-55r) shows the heavily laid-on gold of the initial surrounding the scene of the Nativity drawn in the D; above it is a little piece of cloth sewn in to protect the gold; out of the initial grows a colourful floral border with the Annunciation to Mary among the flowers and a speech bubble for the bird singing a Christmas hymn; ${ }^{5}$ there is musical notation between the lines of text, corrections in the margin, and an added label detailing the psalm tone to be used.

The psalter shows three stages of production which reflect the impact of key events in the history of the convent. The bulk of the manuscript was written around 1500 as a product of the conventual reform in 1479; it was reworked after 1526 when the Duke of Braunschweig-Lüneburg started trying to impose the Lutheran Reformation on Medingen. ${ }^{6}$ That is when fol. $18 \mathrm{v}$, a now forbidden invocation of St John the Evangelist as intercessor, was

\footnotetext{
5 'Hic iacet in presepio qui et sidera regit. Tamquam sponsus'. These are extracts from the antiphon ' $\mathrm{O}$ mundi domina', sung in Medingen at Christmas, cf. Ulrike Hascher-Burger and Henrike Lähnemann, Liturgie und Reform im Kloster Medingen. Edition und Untersuchung des Propst-Handbuchs Oxford, Bodleian Library, MS. Lat. liturg. e. 18 (Tübingen: Mohr Siebeck, 2013), p. 198. The text is commented on in the Low German prayer-books written in Medingen, such as Forschungsbibliothek Gotha, Ms. Memb. II. 84, fol. 23r: 'O mundi domina: O vrouwe der werlde, van konichliken stamme gheboren, uth dynen iuncvrouwelken lyve is Christus nu gheghan alse en brudegham uth synem brutbedde. Hic iacet in presepio: Hir licht he in der krubben dede sterne regeret unde de hemmel.' On the text in the Gotha prayerbook cf. Elizabeth Andersen, 'Das Kind sehen: Die Visualisierung der Geburt Christi in Mystik und Meditation', in: Sehen und Sichtbarkeit in der Literatur des deutschen Mittelalters, XXI. Anglo-German Colloquium London 2009, ed. by Ricarda Bauschke et al. (Berlin: de Gruyter, 2011), pp. 290-310.

${ }^{6}$ For the history of the convent and especially the Manual written for the Provost during the conventual reform cf. cf. Hascher-Burger/Lähnemann, Liturgie und Reform.
} 
crossed out and fol. $19 r$ was written as a replacement prayer (Fig. $5=$ fol. $18 v-19 r$ ). ${ }^{7}$ The second time it was reworked, some time after 1722, when the bulk of the manuscripts from Medingen was sold, a small late-medieval bone plaque and the floral border were glued into the front cover turning it into an antiquarian object (Fig. 6; this is a photograph taken in November 2015 by the auction house for cataloguing purposes, showing the first opening, with the plaque and floral border in place). The story of how the manuscript was produced, annotated, augmented, taken apart, and then finally happily reunited in Oxford allows us to look at the wider issue of manuscripts as objects of devotional, antiquarian and scholarly interest.

II.

The Chair of German medieval studies was established in 1972 by the University of Oxford and attached to St Edmund Hall for Peter F. Ganz, the distinguished literary scholar, who is particularly well known for his Middle High German edition of Gottfried's Tristan. ${ }^{8}$ I had the good fortune to meet him on my first visit to Oxford in 1997 and again in 2005 at the AngloGerman Colloquium, the biennial gathering of German medievalists of which he was a founder and which is one of the reasons why the community of German medievalists in Britain and Germany forms such a strong alliance. ${ }^{9}$ His successor was Nigel F. Palmer who gave his Inaugural Lecture on German literary culture in the twelfth and thirteenth centuries in the Taylorian lecture theatre on 4 March 1993. ${ }^{10}$ During the following years, the cooperation with Germany, particularly with partnership agreements with Bonn and Freiburg im Breisgau, and annual meetings for graduate students of Freiburg, Fribourg, Geneva and Oxford, was built up. I also owe both my first association to Oxford and my first encounter with Medingen manuscripts to him since he invited me to be a guest in the Oxford SubFaculty of German in 2001/2. This led to my first publication on Medingen, which was in Oxford German Studies. ${ }^{11}$

After Nigel Palmer's retirement, the position, the only established chair in Medieval German outside the German speaking countries, was at serious risk. The continuation of it was made possible by the vision and determination of my immediate colleagues Almut Suerbaum and Annette Volfing, the German Sub-Faculty, the Faculty of Medieval and Modern Languages, the Humanities Division and ultimately the University of Oxford. Their readiness to experiment with new forms of sponsorship met with the generosity of the VolkswagenStiftung, the German Academic Exchange Service and the University of Freiburg im Breisgau whose Research Institute of Advanced Studies, the FRIAS, provides a congenial academic environment for two months secondment each year.

\footnotetext{
${ }^{7}$ On the personal patron saints in Medingen and the effects of the Lutheran Reformation on the issue of intercession of saints cf. Henrike Lähnemann, "'Saluta apostolum tuum”. Apostelverehrung in Kloster Medingen', in: Weltbild und Lebenswirklichkeit in den Lüneburger Klöstern, ed. by Wolfgang Brandis and Hans-Walter Stork (Berlin: Lukas Verlag, 2015), pp. 41-64.

${ }^{8}$ Gottfried von Strassburg: Tristan, ed. by Peter F. Ganz (Wiesbaden: Brockhaus, 1978).

${ }^{9}$ Nigel Palmer, 'Professor Peter Ganz', in: Independent, Thursday 14 September 2006 (online via independent.co.uk).

${ }^{10}$ Nigel F. Palmer, German Literary Culture in the Twelfth and Thirteenth Centuries. An Inaugural Lectures delivered before the University of Oxford on 4 March 1993 (Oxford: Clarendon Press, 1993).

${ }^{11}$ Henrike Lähnemann, “AAn dessen bom wil ik stighen”. Die Ikonographie des Wichmannsburger Antependiums im Kontext der Medinger Handschriften', Oxford German Studies, 34 (2005), 19-46.
} 
III.

The 'materiality of medieval manuscripts' is a topic linked to a number of new approaches to medieval studies. This led to a new evaluation of the relationship between the text and its recording on parchment and paper, evident in new methodological lines of enquiry such as the debate in France and the Anglophone countries of what has been called 'New Philology'. ${ }^{12}$ In this context manuscript studies have acquired a new prominence, and in what follows I shall explore what this means for the Medingen prayer-books and psalters. I will introduce my subject, however, by an example from the period half a millennium earlier than the Medingen manuscripts which despite the gap in time is instructive in helping us to understand many of the features the nuns used in their work: this is the Golden Gospel Book from the monastery of Echternach. ${ }^{13}$ What links these codices, produced at very different times and in different places, is how their production, reworking and transmission is intertwined with German political, cultural and literary history.

The Golden Gospel Book from Echternach, the Codex Aureus Epternacensis, exemplifies the representational character which is a major aspect of many medieval manuscripts. The gold in the title refers both to its treasure binding and its text. Its front cover consists of gemencrusted embossed gold metalwork that surrounds an ivory plaque with the Crucifixion. The text is written sumptuously throughout in gold ink. Between the cover and the text lies half a century. The front cover was commissioned around 990 by Empress Theophanu, the Greek-born widow of Emperor Otto II, who at that time was effectively ruling the German realms for her under-age son Otto III. She gave this exquisite piece of workmanship produced in the workshops of the old Roman city of Trier to the imperial abbey of Echternach (nowadays in Luxembourg). What we have here then is the unusual case of a cover that predates the manuscript bound into it.

\footnotetext{
${ }^{12}$ For the continuation of this debate in German medieval studies cf. Karl Stackmann 'Neue Philologie?', in: Modernes Mittelalter. Neue Bilder einer populären Epoche, ed. by Joachim Heinzle (Frankfurt a. M.: Insel Verlag, 1994), pp. 398-427.

${ }^{13}$ Codex Aureus Epternacensis, Nürnberg, Germanisches Nationalmuseum, Hs 156142. Cf. Anja Grebe, Codex Aureus. Das Goldene Evangelienbuch von Echternach (Darmstadt: Wissenschaftliche Buchgesellschaft, 2007).
} 


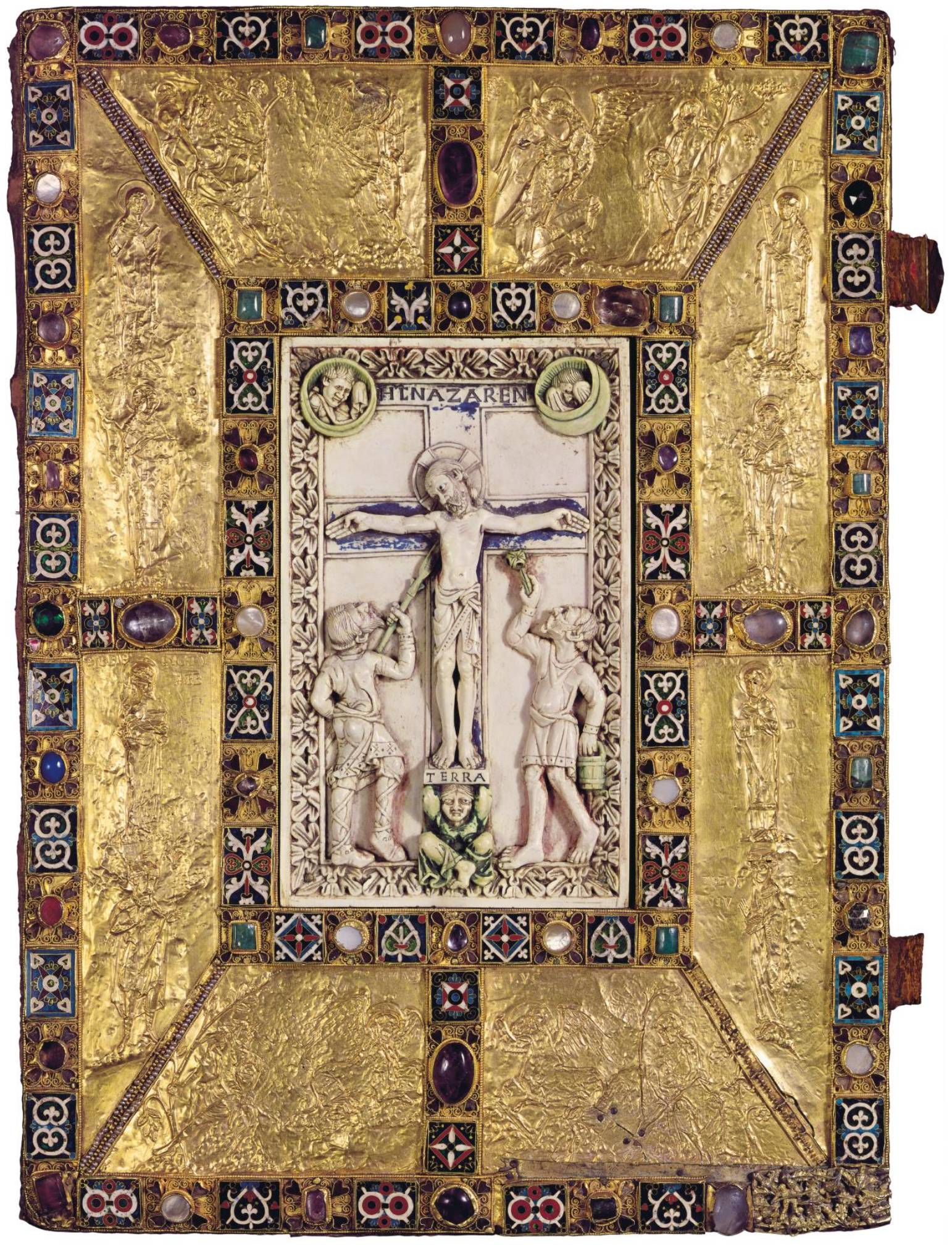

Fig. 3: Cover of the Codex Aureus Epternacensis, Nürnberg, Germanisches Nationalmuseum, Hs 156142, with permission by Germanisches Nationalmuseum, Nuremberg

Theophanu, marked by an inscription as imperatrix, is standing above the river Euphrates, one of the four rivers of paradise. The integrated ivory probably came from a different workshop but shows the same antique style with the heavy bare-breasted personification of 
the earth supporting the crucifix. Together, the ivory, the embossing and the intaglio of precious stones, the enamelled glass and pearls, form a programmatic material unit which all underline the status of the book as the word of God.

The codex the scribes at Echternach produced around 1045 for the cover matches the costliness of the imperial gift. The new lower board was covered with Byzantine silk, held in place by metal clasps lined with differently coloured fabric. The crimson is now faded, but would have been as bright - and as precious - as the jewels on the front. We can get an idea of what this looked like from the manuscript itself. At the beginning of each gospel, the illuminators inserted carpet pages imitating Byzantine textiles. The text is thus approached through multiple layers: from the material gold of the cover via the painted veil of the purple silk to the words. The pages in turn lavishly illuminate by means of their gold ink the word of God which they contain. The text is beautifully laid out in two columns with an initial for the beginning of each gospel reading. On fol. $115 \mathrm{v}$, the initial $E$ opens the second part of the prologue to the gospel according to John, the reading for Christmas Day at the point when the monks would genuflect: 'And the Word became flesh and dwelt among us, and we beheld His glory, the glory as of the only begotten of the Father, full of grace and truth.' ${ }^{14}$

As a liturgical book and the embodiment of the word of God, the Golden Gospels occupied a highly valued place in the churches' treasury. When the French revolution reached Echternach at the end of the eighteenth century, the library was removed to Paris and Strasbourg, but the Gospel book was taken with the relics and other treasures of the church to the supposed safety of the Benedictine monastery at Erfurt. From there it was sold by the French commissioner for the Rhineland to Duke Ernst II of Saxe-Coburg-Gotha for the enormous sum of 120 Carolin (equivalent of 1200 Guilders) and kept as a prized possession in Gotha. In the last weeks of the Second World War, a member of staff of the Duke brought it again into supposed safety out of the realm of the Soviet zone to Coburg, the WestGerman part of the duchy. It was shown in 1950 in the exhibition Ars Sacra in Munich ${ }^{15}$ and attracted considerable interest among American collectors - the Cloisters offered one million dollars for it. In the hectic fund raising which followed, the director of the Germanisches Nationalmuseum, the museum founded in the 19th century as a precursor of German unity, claimed: 'Wenn ein Kunstwerk überhaupt als nationales Denkmal angesprochen werden kann, ist es dieses Buch. Es darf für Deutschland auf keinen Fall verloren gehen'. ${ }^{16}$ Manuscripts can indeed become powerful symbols of regional identity as the strength of feeling surrounding the Lindisfarne Gospels' return to the North East only a few years ago showed. ${ }^{17}$ The campaign for the Golden Gospels was successful and in 1955 the manuscript arrived in Nuremberg - only to be dismantled: the cover went on display in

\footnotetext{
14 'Et uerbum caro factum est. et habitauit in nobis. Et uidimus gloriam eius. gloriam quasi unigeniti a patre Plenum gracie et ueritate' (Jo 1:14f).

${ }_{15}$ Ars sacra. Kunst des frühen Mittelalters: Juni-Oktober 1950, Bayerische Staatsbibliothek. München. Katalog, ed. by Albert Boeckler (Munich: Wolf, 1950).

${ }^{16}$ Grebe, Codex Aureus, p. 22.

17 The Lindisfarne Gospels returned to the North East in 2013 for an exhibition. This was an event which was truly celebrated by people from all walks of life who saw this magnificent work as an embodiment of the region's heritage. Cf. Richard Gameson, From Holy Island to Durbam: the Contexts and Meanings of the Lindisfarne Gospels (London: Third Millennium Publishing, 2013).
} 
the 'medieval treasures' wing of the museum (the book block being replaced by a dummy), while the parchment leaves, now in a new plain cover, were locked away in a safe in library.

In 1982, the book block was further dismembered: the leaves were separated to produce a full-scale facsimile and this provided an opportunity to exhibit most of them side-by-side in the museum. ${ }^{18}$ This facsimile and the catalogue that came with it anticipated a very slow 'material turn' among medievalists which saw the development of an integrated approach to manuscript studies which draws on the curatorial work of museums, philology and art history, while also conceiving of manuscript studies as an aspect of cultural studies. ${ }^{19}$ Thus the Lindisfarne Gospels exhibition in Durham in 2013 devoted several rooms to evoking the period in which the manuscript was produced. The two parts of the Golden Gospels of Echternach are still compartmentalised, but the book block has been sewn together again. Furthermore, the museum has presented online an open-access full digitisation and this has made an on-screen reunification of the carved-up body of the entire Gospel Book possible. ${ }^{20}$

IV.

This brings me to the question of how the manuscripts of the Medingen scriptorium were produced: We can gain an insight into the main coordinates that mark out the astonishing wealth of manuscript production in Medingen by looking at the first psalter produced in the convent, Dombibliothek Hildesheim Ms. J 27, written in 1478..$^{21}$ On the last page, the nun who wrote it explained the production process (fol. 146v). ${ }^{22}$ She uses a highly elaborate and already in her day very antiquated form of rhyming hexameter; this was a Christianised version of the antique metre that had been popular in the tenth and eleventh centuries, at the time of the Codex Aureus, with authors such as Williram von Ebersberg. ${ }^{23}$ The first two lines employ a conventional topos of medieval scribes: that writing requires total commitment from heart, hand, and body: 'Here comes to an end what flows from my innermost heart, written by hand but involving the whole body.' ('Explicit expliciunt, que cordis intima promunt. Scriptando manu, totoque corporis usu.')

The nun, however, specifies the topos further: she adds that both scripta (the written word) and pictura (the pictures) were done by just one famula (handmaiden) - namely

\footnotetext{
${ }^{18}$ Das Goldene Evangelienbuch von Echternach. Codex Aureus Epternacensis Hs 156142 aus dem Germanischen Nationalmuseum in Nürnberg. Faksimile und Kommentar, ed. by Rainer Kahsnitz (Frankfurt a.M.: Fischer and Stuttgart: Müller und Schindler, 1982). The publisher who made the facsimile offered sample pages for sale: Das Goldene Evangelienbuch von Echternach: Codex Aureus Epternacensis Hs. folio 156142 aus dem Germanischen Nationalmuseum in Nürnberg. FaksimileEdition. Einladung zur Subskription (Frankfurt a.M.: Fischer, 1961).

19 The most recent example of an integrated approach to manuscript studies, including philology, codicology and history of art, cf. Jeffrey F. Hamburger and Nigel F. Palmer, The Prayer Book of Ursula Begerin. vol. 1: Art-Historical and Literary Introduction. With a Conservation Report by Ulrike Bürger, vol. 2: Reproductions and Critical Edition (Dietikon-Zurich: Graf, 2015).

${ }^{20}$ The digital reconstruction of a Scriptorium is the next logical step; this is what I try to do with the Medingen website.

${ }^{21}$ Catalogue entry by Renate Giermann and Helmar Härtel, Handschriften der Dombibliothek zu Hildesheim: Teil 2. Hs 700-1050, St. God. Nr. 1-51, Ps 1-6, J 23-95 (Wiesbaden: Harrassowitz, 1993), pp. 173-76.

22 Edition and discussion in Hascher-Burger/Lähnemann, Liturgie und Reform, p. 1.

${ }^{23}$ On the use of the form cf. Henrike Lähnemann, 'Reimprosa und Mischsprache bei Williram von Ebersberg. Mit einer kommentierten Ausgabe und Übersetzung seiner "Aurelius-Vita”. In: Stephan Müller and Jens Schneider (eds.), Deutsche Texte der Salierzeit. Neuanfänge und Kontinuitäten im 11. Jahrbundert (Munich: Fink 2010), pp. 205-37.
} 
herself, 'Elyzabeth de Winsen'. She highlights her own name and the key coordinates of her cloistered life in red ink, i.e. the psalter was written in 'Medingen', situated close to 'Lüneburg' and she, the scribe, belongs to the 'Cistercian' order ('in Meding claustro, Luneborch prope situato. Ordinis ut fateor Cisterciensis et utor', fol. 146v).

In the longest section of the poem, she adds a date for which she draws on three of the seven liberal arts, arithmetic as well as rhetoric and music. Her work on the psalter commenced on Corpus Christi 'in the year one thousand, four times one hundred plus ten, additionally 63 and five more' ('Anno milleno quadruplex centum addito deno, Sexaginta tribus cum quintario sociatus') and was completed on the day when the antiphon Ad te levavi is sung, i.e. the first Sunday of Advent. This adds up to a key date in the history of Medingen: 1478, the year before the advent of the conventual reform which was officially introduced by the provost Tilemann von Bavenstedt, the man named in red further down the page as the person who commissioned the psalter in honour of his aunt, Elizabeth von Bavenstedt.

Both the scripta and pictura executed by Elizabeth von Winsen show a high degree of skill in the production of a codex that draws on features of representational manuscripts from a much older monastic tradition. Psalm 1 starts with the traditional image of King David playing the harp in the gold initial for Beatus vir. There is a clear hierarchy of illumination, the highest level of which is constituted by the ornamental initial with red pen work round the blue body of the letter $Q$ for the beginning of Psalm 2, that contrasts with the plain red and blue capitals used alternately to indicate the beginning of each verse within the psalm. A gold initial opens each major division of the text, ${ }^{24}$ signalling where the nuns would start their daily course of hours; a second such initial is on fol. $26 \mathrm{v}$, the D of Dominus illuminacio mea (Psalm 26) for the following day. The enlightenment provided by the Lord is reflected in the use of the shiny gold for the illumination of the page. Before each division in the psalter, the liturgical opening for the day is given in full choral notation on five lines with a red line to mark the staff for the $f$.

Elizabeth von Winsen also revived the ancient tradition of word illustration, which was to become a characteristic feature of the later Medingen psalters. The foot which on fol. $13 \mathrm{r}$ is attached to the descender of the word 'pes' of Ps 9:15 ('In laqueo isto quem absconderunt: comprehensus est pes eorum') is a visual translation of the verse where it is stated that those setting a trap are caught in their own snare. Whereas the link of the hands of God to the initial $p$ on fol. $43 \mathrm{v}$ of the Bodleian Psalter (Fig. 1) was ornamental, here the twist round the stem has literal meaning.

In the year after the Psalter of Elizabeth von Winsen was written, the provost named in the poem, Tilemann von Bavenstedt, introduced a conventual reform along the lines of the Windesheim Reform Movement. ${ }^{25}$ This included a stricter observance of enclosure and a

\footnotetext{
${ }^{24}$ The basic tripartite division (Ps 1, 50 and 100) is combined with the monastic cursus with further subdivisions for days and hours, cf. Braun-Niehr, Theologische lateinische Handschriften.

${ }^{25} \mathrm{On}$ the relationship of the reform movements to devotional practice and Cistercian identity cf. the chapters by Anne Bollmann, Tanja Mattern, Ulrike Hascher-Burger, Henrike Lähnemann and Eva Schlotheuber in Mysticism and Devotion in Northern Germany in the Late Middle Ages, ed. by Elizabeth Andersen, Henrike Lähnemann and Anne Simon
} 
strengthening of the communal aspect. The nuns embraced this process enthusiastically; a major factor in this was that it afforded them the opportunity to strengthen their identity as Cistercians and also allowed them to play a larger part in the liturgy. They recorded in detail this change in the handbook that was made for the provost; the nuns had compiled it originally for his inauguration a few years earlier and now completely updated it to reflect the new liturgy of 1479. When one opens the handbook, the traces of cuts, pasted-in half pages and rubbed-out sections make it immediately clear that radical editing was necessary to bring the music and the instructions for the provost up to date. It is on the basis of these manuscripts from the years of the reform in 1478/1479 that each of the nuns in Medingen started to produce her own psalter and prayer-books, providing, as Elizabeth von Winsen had done, both text and images by her own hand.

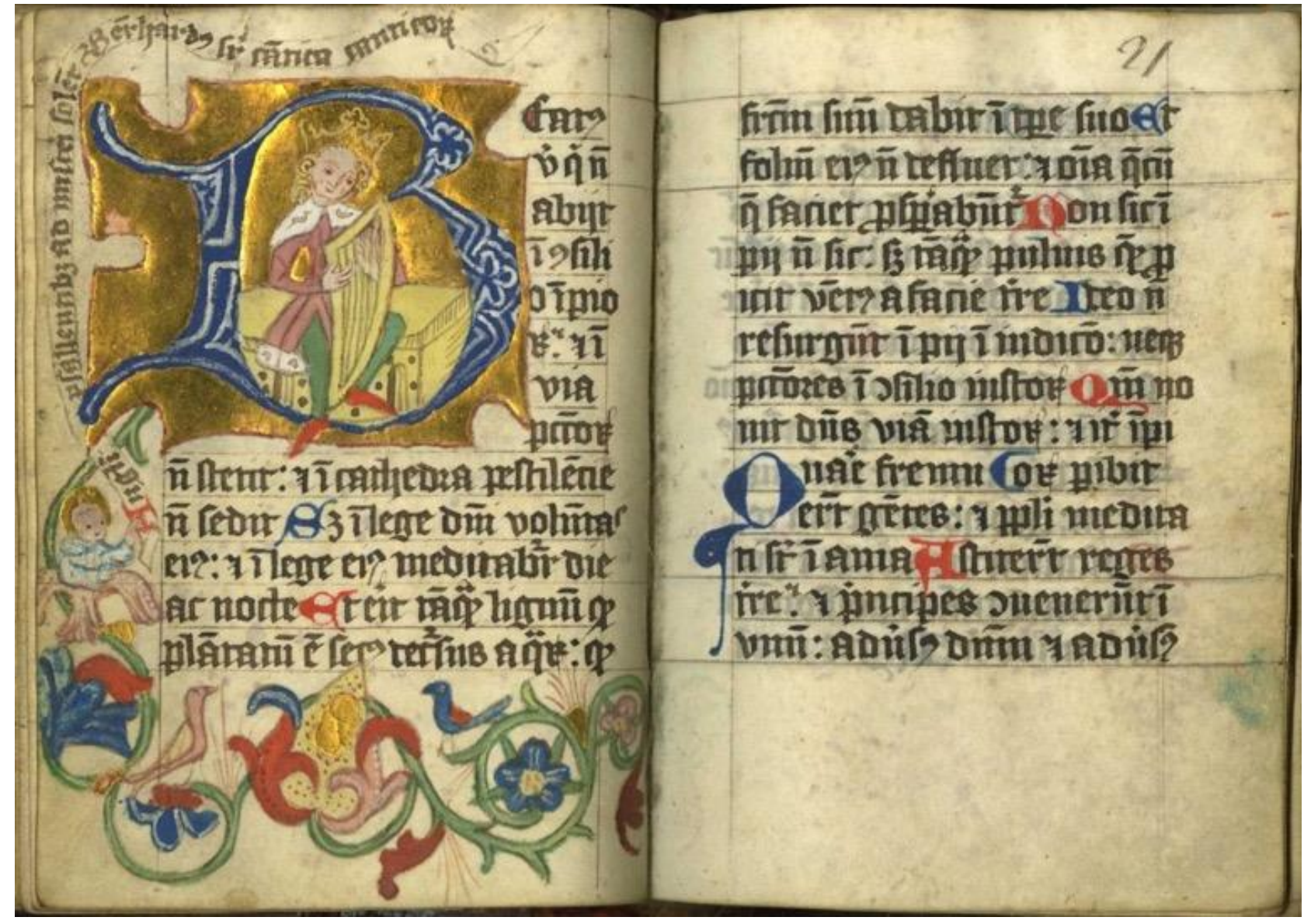

Figure 4: Oxford, Bodleian Library, MS. Don. e. 248, fol. 20v-21r.

The Bodleian Medingen Psalter is a result of this process. The historiated initial for Psalm 1 has the image of David playing the harp with the same heavy use of thickly laid-on goldleaf as in the Psalter of Elizabeth von Winsen. What sets it apart from the earlier model are several distinctive Cistercian features that signal that it was written after the reform of 1479 when the nuns' alliance to the order was strengthened. On the left is what was described in the American auction catalogue as a 'baby within a flower' ${ }^{26}$ but which in fact is the talking

(Leiden: Brill, 2014); specifically on the repositioning of the Medingen nuns as Cistercian cf. Hascher-Burger / Lähnemann, Liturgie und Reform, pp. 17-35 and 90-98.

${ }^{26}$ Many thanks to Laura Light who alerted me to the manuscript in the first place and sent me photographs and her unpublished description in advance of the exhibition; a shorter version of the description is published in the 
head of Bernard of Clairvaux. He is shown in the white habit of the Cistercian order with a tonsured head and a halo, holding a scroll as a speech bubble which states: 'Angeli psallentibus admisceri solent' ('Angels like to join in with those chanting the Psalms'), a quotation from one of Bernard's sermons on the Song of Songs, as Margaret Hopes, the scribe, rightly noted. The nuns were able to draw on a large library; it was destroyed by fire in the eighteenth century, but we can get a fairly accurate picture of the range of their reading by looking at the surviving books of the neighbouring convents on the Lüneburg Heath which show that the libraries were well stocked with theological commentaries both in manuscript and print form. ${ }^{27}$ The other Cistercian feature on the page is the punctuation mark in the sixth line which looks like an upside-down semicolon; this is a punctus flexus which is characteristic of Cistercian punctuation. ${ }^{28}$ These features, together with the gold, the formal Gothic hand, the use of parchment and the careful layout with a hierarchy of decoration and alternating red and blue initial letters for the verses all demonstrate a highly reflective and specific use of the medium of the 'manu-scriptum'. At the point Margaret Hopes was writing, some time around 1500 , printed psalters were readily available. It was by choice, not from necessity, that she produced a personal copy of the Psalms as a precious object, enhancing it by combining elements which were typical of representational manuscripts as far back as the Golden Gospels with that feature of personalised compilation so characteristic of late medieval devotional writing.

This personalisation can be seen especially in the margins. Word illustrations similar to the hands of God writing the world are scattered throughout the manuscript and linked to key phrases. Twice they take the form of a baby, representing the medieval concept of the soul, helpfully labelled as 'anima'. Psalm 15:10 speaks with the words made famous by Handel's Messiah that 'thou wilt not leave my soul in hell' ('non derelinques animam meam in inferno', fol. 36v); through the image of the soul dangling from the descender of the letter $q$ the reader is able to visualise the daily danger from which the praying of psalms could protect you.

In Psalm 30, the soul is in a similarly precarious position: Margaret Hopes chose to illustrate a verse which complains that adversaries have conspired to take away one's life or in the Latin phrase 'accipere animam' - to seize the soul (fol. 60r). The person praying counters this by saying: 'In you have I hoped, Lord; ... my lot is in your hands, tear me from the hand of my enemies.' (Ps 30:15) The soul labelled again as 'anima' raises up her hands imploringly while she is grabbed by two snake-like arms, wound as a double helix around the descender of the $p$. The layout of the page has been used to turn this into a dramatic attempt at escape. While the scribe was otherwise very careful to write only within the ruled

\footnotetext{
catalogue Laura Light, Women and the Book in the Middle Ages and the Renaissance (Paris, Chicago, and New York: Les Enluminures, 2015), pp. 52-55, available online at textmanuscripts.com, including a double-spread illustration of fol. $20 \mathrm{v}-21 \mathrm{r}$.

${ }^{27}$ Cf. Renate Giermann and Helmar Härtel, Handschriften des Klosters Ebstorf (Wiesbaden: Harrassowitz, 1994).

${ }^{28}$ Cf. Nigel F. Palmer, “'Simul cantemus, simul pausemus”. Zur mittelalterlichen Zisterzienserinterpunktion', in: Lesevorgänge. Prozesse des Erkennens in mittelalterlichen Texten, Bildern und Handschriften, ed. by Eckart Conrad Lutz (Zurich: Chronos Verlag, 2010), pp. 483-569.
} 
space on the page, both the word 'animam' in the text and the child figure in the drawing are crossing the border, underlining the hopeful cry for help.

The emphasis on the plea of the soul links the text of the Psalms to the appendix of the manuscript, which consists of the Office of the Dead. This is written out according to the Cistercian rite for the specific case of the burial of a sister from the convent, as the prayer on the top of fol. 278 r specifies: 'Tibi domine commendamus animam famule tue' ('We commend to you, Lord, the soul of your handmaiden'). The provost would perform the official funeral, but these are the chants for the leave-taking performed by the convent internally.

The commemoration of the dead extended beyond the cloistered community. Here the first quire of the manuscript fulfils a key function, the calendar, an obligatory part of each of the Medingen psalters providing information about the family network of the scribe both on earth and in heaven, since it lists the days for commemoration and highlights favourite saints' days. The red entry for 14 December as the day on which 'Dietrich Hopes, my most dearly beloved father, died' ('Obiit Dydericus hopes pater meus amantis[simus]', fol. 12v) allowed the identification of the scribe as Margaret Hopes, who is mentioned in 1524 as a member of the election committee for the new abbess in her role as cantrix - one of the leading offices in the convent. On the same double spread in the calendar (fol. 13r), 27 December is highlighted as being even more than a red-letter-day by mixing red and blue characters for noting down the feast day of John the Evangelist; this is part of a custom at Medingen whereby the nuns chose apostles as their personal patrons. The Keble prayerbook from Medingen, dedicated to the apostle Thomas by its scribe Elizabeth Elebeke, is part of the same devotional practice of singling out one apostle as special intercessor.

A particularly striking example of the close bond the nuns felt for their apostles, especially on their feast day, can be seen in the apostle prayer-book written by the nun Barbara Viskule for St Bartholomew in the Victoria and Albert Museum..$^{29}$ The miniature on fol. $45 \mathrm{v}$ shows him stretched on the bench with his skin hanging down and being nibbled by a dog. If you follow the instruction on the page to greet the 'skinned-alive apostle' ('Saluta vivum excoriatum apostolum', written again in mixed red and blue highlighting, fol. 46r) by reading on, you realise that there is a hole in the parchment, circled in red - and this flaw in the stretched animal skin has been turned into a peep-hole to keep your eye fixed on the saint. ${ }^{30}$ The nun thus relates the materiality of parchment to her personal devotion to the martyred patron saint.

The third family group mentioned in the calendar, in addition to the relatives and the saints, is the community of the convent, whose obits were recorded to include them in the

\footnotetext{
${ }^{29}$ London, National Art Library, MSL/1886/2629, cf. Henrike Lähnemann, 'Schnipsel, Schleier, Textkombinatorik. Die Materialität der Medinger Orationalien', in: Materialität in der Editionswissenschaft, ed. by Martin Schubert (Tübingen: Niemeyer, 2010), pp. 135-46.

${ }^{30}$ On the use of holes as pictorial elements of the page cf. Phillipa Hardman, "The Mobile Page: "Special Effects" in Some Late Medieval Manuscripts', in: Tributes to Kathleen L Scott: English Medieval Manuscripts: Readers, Makers and Illuminators, ed. M. V. Hennessy (Turnhout: Brepols, 2009), pp. 101-13; on the interplay between Bartholomew's martyrdom and its presentation in manuscript format cf. Sarah Kay, 'Original Skin: Flaying, Reading, and Thinking in the Legend of Saint Bartholomew and Other Works', Journal of Medieval and Early Modern Studies, 36 (2006), pp. 35-74.
} 
cycle of prayers. This provides us with a terminus ante quem for the Bodleian Psalter. In 1513, Margaret Puffen died, a nun who was brought in from Kloster Wienhausen to oversee the internal reform of Kloster Medingen and went on to become the first abbess. Margaret Hopes highlights the fact that she died on 13 July, their shared name day, by linking the entry for St Margaret with that for the abbess, adding as a personal note that Margaret Puffen was a 'most faithful abbess and most beloved mother' ('abbatissa fidelissima ac precordialissima mater', fol. 7v).

The calendar thus demonstrates the close-knit community of the dead and the living, the township and the convent. Books went to and fro: the nuns sent their finished manuscripts in batches to Lüneburg workshops to be bound as the identical pomegranate motive used as a binding stamp on several covers shows, among them the apostle prayer-book in Keble College. ${ }^{31}$

Manuscripts were also specifically written for the townspeople. The nuns felt responsible for the spiritual well-being of Lüneburg, their home town, and provided the lay-women there with reading matter. This outreach to lay-people is especially noticeable in the prayer-books in which the nuns provide devotional instruction. The Medingen prayer-book Forschungsbibliothek Gotha, Ms. Memb. II. 84, ${ }^{32}$ was written for Anna Töbing, née Elebeke, wife of the Lüneburg mayor. Her sister was Elizabeth Elebeke, the Medingen nun who wrote the Keble prayer-book. ${ }^{33}$ The prayer-book follows the church year. The nun here explains as a liturgical guide the elements of the mass on Christmas morning and why everybody is supposed to genuflect at the reading of the prologue of the Gospel according to John: 'When the words are sung: The Word was made flesh, and dwelt among us, and we beheld his glory... Who should have a heart of stone not to be moved by these sweet words: 'God's son was made man.' Therefore, my beloved, fall on your knee with the full devotion of your heart...'.$^{34}$

The nuns, in their writing, take on the pastoral role of interpreter for the laity. They act with spiritual independence and authority based on a strong sense of standing in a monastic tradition which had been fully reformed in 1479. This is one of the main reasons why they did not take kindly to the attempt by Duke Ernst of Braunschweig-Lüneburg to impose Protestantism on them. In 1526, he sent them an early copy of Luther's translation of the New Testament into Low German - which the then abbess threw into the fire in the abbey's

\footnotetext{
${ }^{31}$ The exact motif is not listed in the database of medieval tooling, http://www.hist-einband.de/; the closest is EBDB s004819 'Granatapfel 1' ascribed to the Benedictine Abbey St John the Baptist in Uelzen, the town closest to Medingen, on the basis of ownership marks. The pomegranate stamp from the Bodleian Medingen Psalter can be found on at least five other bindings of Medingen manuscripts. On the discussion of whether there was a workshop in Medingen cf. Hascher-Burger/Lähnemann, Liturgie und Reform, pp. 176-78.

32 Online at archive.thulb.uni-jena.de, catalogue: Cornelia Hopf (ed.): Die abendländischen Handschriften der Forschungsund Landesbibliothek Gotha. Bestandsverzeichnis. Teil 2: Kleinformatige Pergamenthandschriften Memb. II (Gotha: Forschungsund Landesbibliothek, 1997), p. 55-56.

33 On the sisters cf. Henrike Lähnemann, 'Medinger Nonnen als Schreiberinnen zwischen Reform und Reformation', in: Rosenkränze und Seelengärten. Bildung und Frömmigkeit in niedersächsischen Frauenklöstern, ed. by BrittaJuliane Kruse (Wolfenbüttel: Herzog August Bibliothek, 2013), pp. 37-42.

34 Wanme singhet: Verbum caro factum est et habitavit in nobis, et vidimus gloriam eius... (Jo 1:14) We is nu stenen van herten, dede nicht beweghet werde van dessen soten worden: Gode sone is minsche worden. Darumme, leve minsche, bughe dy kny myt ghanser andacht dines herten...', fol. $21 \mathrm{v}$.
} 
brewery. The place where this happened is still visible, as the Gothic brick building is the only one to have survived the fire in the eighteenth century. This act of defiance started what the nineteenth-century historiographers called 'the nuns' war', which ended after thirty years in an astonishing compromise that ensured the convent's survival to this day. ${ }^{35}$ The nuns were allowed to continue their way of communal life in the convent, to keep their Latin liturgy and their Cistercian habit, but they had to concede on a number of dogmatic points. The most important was to abstain completely from invoking the saints as intercessors. Here we come back to the Bodleian Psalter, which shows clear evidence of how this injunction was put into practice in the middle of the sixteenth century when the compromise with the Duke was reached.

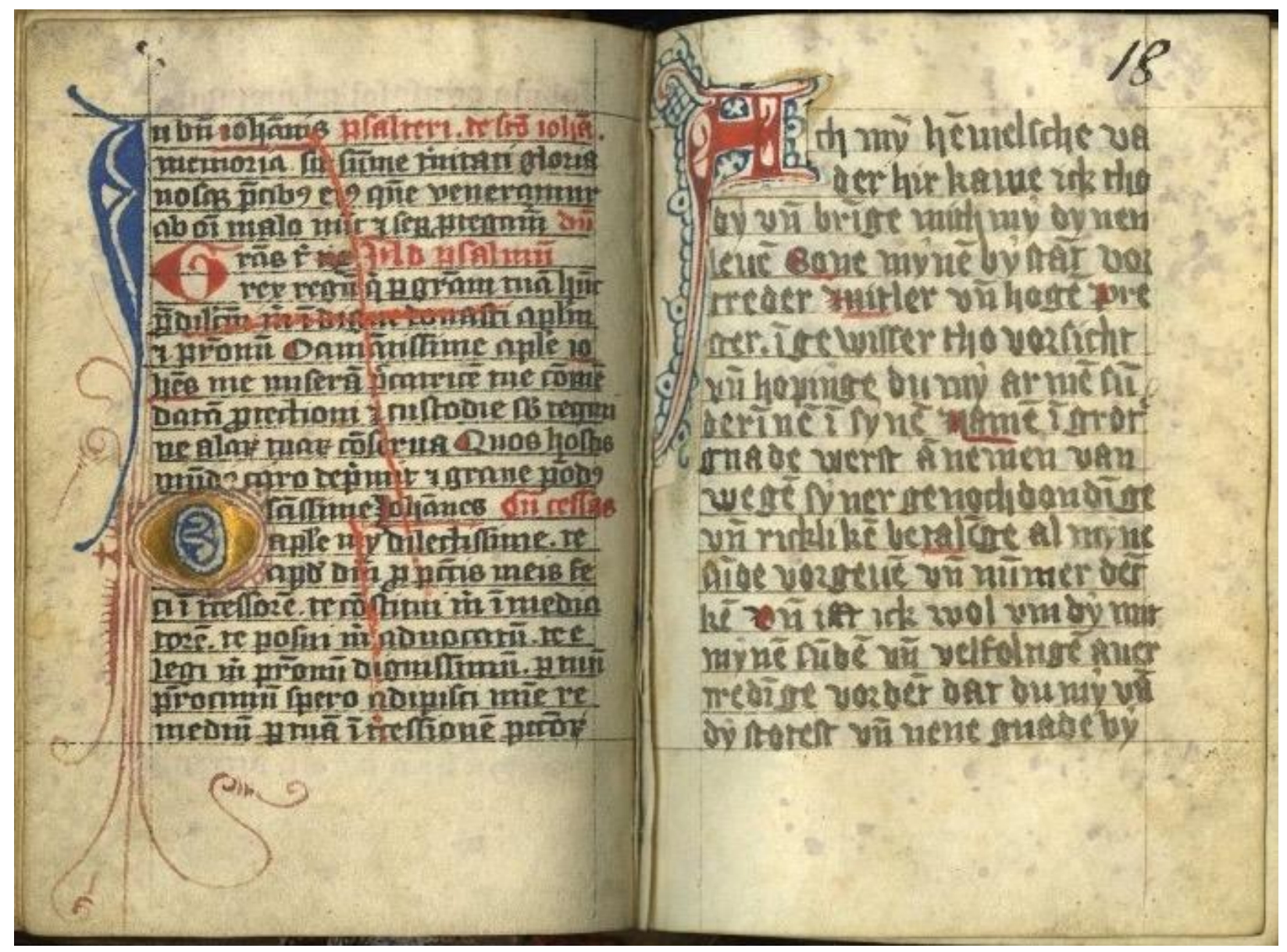

Figure 5: Oxford, Bodleian Library, MS. Don. e. 248, fol. 18v-19r.

At the beginning of the manuscript, there were a number of tables added to the calendar to calculate time in the course of monastic life, showing, for example, the time of sunrise at different times of the year to determine when to get up for Divine Office. ${ }^{36}$ Directly on the back of the table for sunsets an intercessional prayer follows, addressed to John the Evangelist, the saint who had been highlighted in the calendar. He is invoked after the gold initial as 'my most dearly beloved apostle' ('apostole my dilectissime', fol. 17v, Fig. 5). The

\footnotetext{
${ }^{35}$ Cf. Henrike Lähnemann, 'The Medingen "Nuns' War"', in: The Northern Experience. Mysticism, Art, and Devotion between Late Medieval and Early Modern, Antwerp Conference 2011, special issue of Ons Gesteliijk Erf, ed. by Kees Scheepers (forthcoming).

${ }^{36} \mathrm{~A}$ full list of these tables and their explanation for the Medingen psalters in the catalogue entry for Berlin, Ms. theol. lat. oct. 189, in Braun-Niehr, Theologische lateinische Handschriften.
} 
nun who has chosen him as her personal mediator hopes to gain through his intercession mercy from God. Here the prayer stops in mid-sentence, because the next two pages are cut out. It is clear why: for a Lutheran understanding, this was assigning a role to the apostle which was appropriate only for Christ. However, the start of the prayer was allowed to remain on the page since cutting it out would have also taken away the table for sunset. Instead, it is rendered invalid by crossing it out. This crossing out is done ingeniously: not only does it not obliterate any of the text, it even highlights the discarded saint by linking by means of a cross the two mentions of the name 'iohannis' which had been underlined in the same red that is used for the crossing out.

This prayer was then replaced by an address in the vernacular to God the Father, calling for mercy by pointing to Christ as intercessor: ' $O$ my heavenly father, I come here to you and bring along with me your dear son, my supporter, advocate, mediator and High Priest, in the firm trust and hope that you will receive me, poor (female) sinner in His name, in great grace, and that because of the satisfaction and rich payment he has rendered you will forgive all my sins and will no longer remember them.' ${ }^{37}$

Christ is pointedly addressed as 'intercessor', linking him with highlighted key words from the Protestant debate such as 'mediator' and 'payment'. This is distinctly different from the style in which the nuns addressed Christ as bridegroom and dialogue partner in the Low German prayer-books. What links the Protestant prayer to the earlier plea for apostolic intercession is the cut-out and glued-in initial - likely to be a salvaged piece from the slashed address to John the Evangelist. Cutting and pasting seems to have been a real fashion in Medingen. In the prayer-book Oxford, Bodleian Library, MS. Lat. liturg. f. 4, fol. 141v, a little maiden is cut out from an early print; she and two lions glued-in at another page of the manuscript were the reason why this manuscript made it into the incunable catalogue of the Bodleian library. ${ }^{38}$

The reworking which the Reformation entailed builds on the procedures used for correcting text developed in the nuns' own reformation, that is the conventual reform of the fifteenth century, as the adjustments made to the manual for the Provost showed. The Bodleian Psalter has an astonishing number of textual corrections and other amendments. At the beginning of Psalm 30, the nun added the missing verse 4 in the lower margin of fol. 60r. The tiny blue initial for this was done as a cut-and-paste job - as in fact was the large blueand-gold initial at the opening of the Psalm.

\footnotetext{
37 'Ach myn hemmelsche vader, hir kame ick tho dy vnde bringe mith my dynen leuen Sone, mynen bystant, vortreder, Mitler vnde hogen Prester; in gewisser thovorsicht vnde hopinge, du my armen sunderinnen in synem Namen in groter gnade werst annemen van wegen syner genochdondinge vnde rickliken betalenge al myne sunde vorgeuen vnde nummer dencken', fol. 18r.

${ }^{38}$ Cf. Nigel F. Palmer, 'Blockbooks, Woodcut and Metalcut Single Sheets', in: A Catalogue of Books Printed in the Fifteenth Century now in the Bodleian Library, ed. Alan Coates (Oxford: Clarendon Press, 2005), p. 45. Online on http://www.bodleian.ox.ac.uk. She has been used as the figure-head for the official Twitter account of Medieval German Studies at Oxford, adding a new twist to her history of being cut-and-pasted across different forms of literary representation, https:// twitter.com/medgermox (accessed 17 January 2016).
} 
The addition of the ornamental initial at the beginning is likely to be connected with the musical notation..$^{39}$ It marks the start of a new subsection of the text with the antiphon for the preceding monastic hour given at the end of the last psalm, to be sung in the eight psalm tone ('octavus tonus'). For the antiphon Adorate dominum only the first two syllables 'Ado' are given as a reminder and, above the 'octa' for 'octavus', the melodic formula for the end of the doxology 'seculorum amen'. The second antiphon, opening the next psalm section, is nearly identical with the second half of the first verse of Psalm 30 and so the musical notation for these is squeezed in between the lines of the text of fol. 60r. This combination is the same as in the Hildesheim Medingen Psalter that Elizabeth of Winsen had written in 1478.

These aide-mémoires for liturgical use might have been added when Margaret Hopes became cantrix and thus had to lead the singing of the nuns in the choir stalls. This practice of antiphonal chant of the Latin Psalms remained firmly in place when the convent had become, at least in name, Protestant. The nuns thus crossed the threshold of the Lutheran Reformation with minimal changes in their devotional routine. They used their skills of correcting and updating acquired in the fifteenth century to adapt to the new liturgical regime of the sixteenth century. The nuns continued to use Latin for their worship and wear their Cistercian habit well into the seventeenth century. The breaking point seems to have been the Thirty Years' War (1618-48) when the treasures of the monastery were boxed up. Costly and authoritative things like the silver crozier of the abbess were later taken out again, but their prayer-books had become obsolete. The first manuscript to leave the convent that we can date was a prayer-book donated to a librarian in Hanover by Abbess Anna Laffert shortly before her death in 1722.40

Anna Laffert's successor seems to have taken this development to a new level. We know about this because of the wave of antiquarianism in the first half of the eighteenth century, which saw a monumental documentation of the history of the Medingen convent by the local minister Johann Ludolf Lyßmann (1685-1742). ${ }^{41}$ This is a decidedly Protestant review of the history of the convent, praising the 'advent of the blessed Luther' and his equally glorified secular missionary, Duke Ernst. Lyßmann notes with regard to his contemporary, the abbess Katharina von Stöteroggen (1722-1741), that she was 'friendly and courteous to everyone. Even though she had a considerable talent for German and Latin and a solid grounding in Greek and Hebrew and was overall well versed in the liberal arts, she did not boast about it at all. During the time in which she presided over the Abbey, she was

\footnotetext{
${ }^{39} \mathrm{I}$ am indebted to Ulrike Hascher-Burger who provided me with transcriptions and comparative material for the antiphons. Her catalogue is the most comprehensive survey of music in the manuscripts of the Northern German convents: Ulrike Hascher-Burger, Verborgene Klänge. Inventar der handscbriftlich überlieferten Musike aus den Lüneburger Franenklöstern bis ca. 1550 (Hildesheim: Olms, 2008).

40 A Low German prayer-book for Christmas, Staats- und Universitätsbibliothek Göttingen $4^{\circ}$ Cod. Ms. Theol. 242. More on the stages of manuscript distribution from Medingen to the libraries in Henrike Lähnemann, 'The Medingen Manuscripts in the Houghton Library. Houghton MS. Lat. 395 and Houghton MS. Lat. 440’, Harvard Library Bulletin (forthcoming).

${ }^{41}$ Johann Ludolf Lyssmanns Historische Nachricht von dem Ursprunge, Anwachs und Schicksalen des im Lüneburgischen Herzogthum belegenen Closters Meding, dessen Pröbsten, Priorinnen und Abbatißinnen, auch fürnehmsten Gebräuchen und Lutherischen Predigern \&. nebst darzu gehörigen Urkunden und Anmerkungen bis auf das Jahr 1769 fortgesetzt (Halle: Gebauer, 1772).
} 
universally liked and respected. She increased the income of the convent substantially by selling to the advantage of the convent many superfluous precious objects that had been kept in boxes since the Thirty Years' War, and invested the money. She served God with sincerity and set an example to all those in the convent in observing the monastic constitution as well as true divine service...'. ${ }^{42}$

This is most likely the date when the Bodleian Psalter left Medingen. It then turns up in the nineteenth century in the library of Friedrich Gottlieb Julius von Bülow zu Beyernaumburg. In the mock-medieval extension to his family seat near Halle he amassed nearly 30.000 books, among them 1763 manuscripts. ${ }^{43}$ The psalter was listed in the third volume of the Bibliotheca Büloviana by Georg H. Schäffer and the note on the lower pastedown shows that it was auctioned off on 7 April 1836.44

The next station in its journey that we are certain of is that it came into the possession of the Brockdorffs, a noble family from Holstein. It was probably bought by Count Ulrich von Brockdorff-Rantzau who was a notable book collector; as Minister of Foreign Affairs he led the German delegation to Versailles in 1919, but resigned rather than signing the Treaty. When a Swiss auction house bought the historic family collection in the 2010s, the oldest item in it was the psalter and the newest a copy of the Treaty of Versailles with BrockdorffRantzau's marginalia. ${ }^{45}$

Between the family seats of the Bülows and the Brockdorffs, the psalter underwent its second major overhaul: the addition of a plaque showing Pilate washing his hands, glued into the cover with a paper passe-partout of painted flowers. (Fig. 6) In the sixteenth century, the binding had been taken apart when two single leaves with the Low German prayer were added, one hooked around quire two, the other hooked around quire three. For this the book block had to be taken apart, re-sewn and glued back into the cover, leaving a slightly patchy appearance as the final opening still shows.

42 ‘...gegen jedermann freundlich und holdselig. Ob sie gleich in der teutschen und lateinischen Sprache eine grosse Fertigkeit, und in der griechischen, auch hebräischen eine gute Kentniß, sich auch überhaupt in den schönen Wissenschaften wol umgesehen hatte: so war sie doch darauf nicht stolz. Die Zeit, welche sie dem Closter überaus rühmlich vorgestanden, erwarb sie sich allgemeine Liebe und Ehrfurcht. Sie vermehrete die Einkünfte des Closters dadurch beträchtlich, daß sie viel unnöthige kostbare Sachen, welche seit dem dreyßigjährigen Kriege in Kasten eingepackt gestanden, dem Closter zum Besten verkaufte, und das Geld zu Capitalien machte. Sie dienete GOtt mit redlichem Herzen, und führete die sämtliche Conventualinnen so wol zu Beobachtung der Closterordnungen, als des wahren Gottesdienstes an' (Lyssmanns Historische Nachricht, p. 173).

${ }^{43}$ Cf. the doctoral thesis Halle 1916 on the manuscripts which came into the Bülow collection from the Benedictine monastery in Erfurt by Joseph Theele, Die Handschriften des Benediktinerklosters St. Petri in Erfurt (Salzburg: Pustet, 1916), p. 36-37.

${ }^{44}$ Bibliotheca Büloviana, das ist systematisches Verzeichnis der zum Nachlasse des verstorbenen Herrn Stiftsregierungsraths Friedrich Gottlieb Julius von Bülow zu Beyernaumburg bei Sangerbausen gebörigen [...] Sammlung von Büchern und Handschriften [...] von Georg Heinrich Schäffer, Teil 1-3 (Sangerhausen, 1834-36). The manuscript is listed in part 3 (1836), p. 48, in the section 'Theologie, in octavo et forma minori' as 'Nr. 621 Liber precum. Membr[ana] von 284 Bl[ättern], mit 8 vergold[eten] Miniat[uren] (von 1 Zoll Höhe und Breite) u[nd] vielen vergold[eten] Init[ialen].' The entry at the end and the foliation of the Psalter are in the hand of the library secretary, Georg Heinrich Schäffer. My thanks to Beate BraunNiehr for checking the catalogue.

${ }^{45}$ I am grateful to Andreas Terwey from Koller Auktionen for having provided extensive information on the acquisition history. The manuscript was described by Gaudenz Freuler as a 'Breviarium' which he classed as 'modest work' ('bescheidene Arbeit') with 'antiquated style' ('rückständiger Malstil') in the auction catalogue (online at kollerauktionen.ch) and sold as Lot 178 on 21 September 2013, 10am, for CHF 30.000. The description lists the plaque as ivory and the floral border as 'provincial transformation of standard decoration used in the second half of the fifteenth century' ('provinzielle Umformung in der zweiten Hälfte des 15. Jahrhunderts in der deutschen Buchmalerei gängiger Dekorationsprinzipien'). 


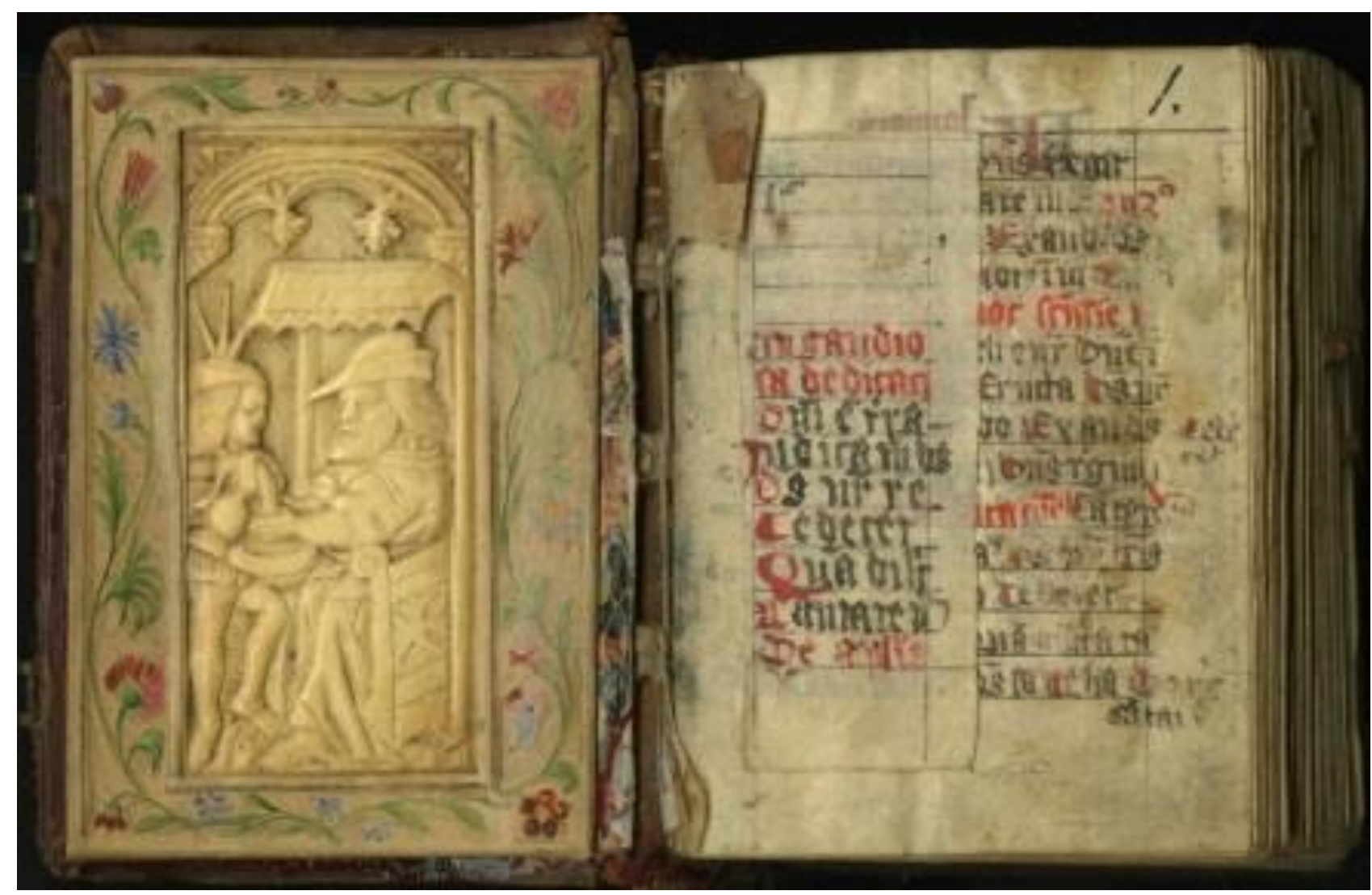

Figure 6: First opening of the psalter with plaque and floral border in place, photographed in November 2014 by Laura Light.

This left the manuscript susceptible for embellishments in the Gothic style of the nineteenth century. At the same time, for example the English antiquarian Edward Hailstone who owned the Manual for the Medingen provost added his neo-Gothic coat of arms to the leather cover. ${ }^{46}$ In the case of the Bodleian Psalter the addition seems to have been inspired by older bindings, but was added to the slightly ruffled inside of the cover.

The most likely person to have added to the psalter in this way would have been an antiquarian dealer trying to further enhance the material aspect - and value! - of the manuscript. Heinrich Lempertz of Cologne bought the largest number of books at the auction of the Bülow library. ${ }^{47}$ He published books with engravings showing the covers of rare and precious manuscripts. ${ }^{48}$ The addition to the psalter shows an attempt to imitate two medieval manuscript fashions. The first is the integration of ivory panels in early representational codices such as the cover of the Golden Gospels of Echternach. The panel in the case of the Bodleian Medingen Psalter seems to have come from a bone casket of the type documented in a Chicago collection which shows that the panel with Pilate would have had a continuation in further scenes from the Passion of Christ. ${ }^{49}$ These were popular affordable imitations of

\footnotetext{
${ }^{46}$ Hascher-Burger/Lähnemann, Liturgie und Reform, p. 185-87.

47 Theele, Handschriften des Benediktinerklosters, p. 37. The auction house Lempertz is still dealing in Cologne; cf. www.lempertz.com.

${ }^{48}$ Heinrich Lempertz, Bilder-Hefte zur Geschichte des Bucbhandels und der mit demselben verwandten Künste und Gewerbe. 65 Tafeln mit bildlichen Darstellungen in Kupferstich, Lithographie, Farbdruck und Holsschnitt, mit Text (Cologne: Lempertz, 185365).

${ }^{49}$ Bone casket showing scenes from the Life and Passion of Christ, Netherlands c. 1430-60, Chicago, Loyola University Museum of Art (LUMA), Inv. 1984-03. Information provided by the cataloguer of the plaque for Sam
} 
earlier ivory caskets and were produced in the Southern Netherlands in the fifteenth century. After the dissolution of the monasteries in the Rhineland under Napoleon, the market was awash with broken-up religious objects like this. The panel is in a way a very appropriate addition to the type of manuscript produced in Medingen: both take up earlier forms of religious and devotional culture in a retro-style which fitted in nicely with the antiquarian interests of the nineteenth century.

Another popular medieval device is the framing of devotional scenes by a floral border, exemplified par excellence by the professionally produced books of hours in the thirteenth to fifteenth centuries. There are plenty examples available for comparison, e.g. the border around St. Francis receiving the Stigmata in the Book of Hours Oxford, Bodleian Library, MS. Douce 112, f. $161 .^{50}$ In the case of the Bodleian Medingen Psalter, the floral border in the first line was added mainly as a practical device to hold the plaque in place, but it also provides a visual link to the illuminated part of the manuscript where, for example, in the Beatus initial on fol. 20v floral elements are used as a frame.

The stations of the manuscript so far were thus probably five: Medingen, the castle of Beyernaumburg, possibly the Rhineland, Schleswig-Holstein where the Brockdorff family had their homes, then Zurich where in September 2013 it was bought at the annual auction by an American auction house specialising in medieval manuscripts.

The American auction house was at that point putting together an exhibition of manuscripts written or owned by women and offered for sale. ${ }^{51}$ When I was giving a lecture at Harvard during my work on the Medingen prayer-books there in September 2014, I was approached by the curator for the exhibition and asked whether I could identify the manuscript. ${ }^{22}$ From the photographs she sent me, it was immediately possible to trace it back to Medingen. A week before the scheduled start of the exhibition, the Keeper of Special Collections and Bodley's Librarian were going to New York and offered to take a look at the manuscript which was just going to be exhibited. I then received an email with the exciting news that it might be possible for the library to buy it. Attached to the e-mail were some photos taken with a mobile phone. One of them was of the inside cover - which was empty except for a new paste-down. I wrote by return-email asking them a) to buy the manuscript, b) to enquire about the panel - and we were told that it 'got detached'. When the dealer was pressed to give further detail about this detachment, the whereabouts of the plaque were revealed to be in London at yet another auction house. What seems to have been the decisive factor in the detachment of the plaque was that it was thought to be made, like the early medieval manuscript covers, from ivory, a material which in the States may neither be imported nor exported because ivory is classified as originating from an endangered species.

Fogg (samfogg.com) where the plaque was listed in the unpublished sales document (as item 16409). A full catalogue entry is available on the website of the Gothic Ivories Project at The Courtauld Institute of Art, London, www.gothicivories.courtauld.ac.uk (accessed on 25 January 2016; under inventory number 1984-03).

50 Accessible on the Bodleian Special Collections DIYdigitisation flickr site ('bodspecialcollections' auf flickr.com, under 'floral border'): Book of Hours. Use of Rome, uploaded by Renzo Dionigi.

${ }^{51}$ Laura Light, Women and the Book.

52 The lecture, together with the contributions on aspects of the Medingen manuscripts by the students from the University of Connecticut, will be published in the Harvard Library Bulletin. 
Had the dealers consulted the Bodleian Conservation department they could have learned that in all probability the skeletal material comes from a Dutch cow - not exactly an endangered species. The official argument was that it was a later addition anyway and therefore not an integral part of the manuscript. Fortunately, the Bodleian took a different view and the case for acquisition was put for both the manuscript and the plaque. When I went to the London auction house where the manuscript had been brought for examination by the Art Fund, I saw the manuscript and the plaque but not the floral border which had held the plaque in place inside the upper board. When I asked what had happened to the passe-partout, I was simply told that it had been 'lost in transit'.

Neither the Bodleian nor I were very happy with the answer, some email exchanges occurred - and lo and behold, two days later I was sent a photograph of the detached border; only some slight cracks in the paper tell of its temporary disappearance, the sale went through and I was able to photograph all three parts of the manuscript, united once more, in September 2015 in the Weston Library.

Having come full circle, I want to finish by drawing attention to the opening from the psalter (Fig. 2) which I think is the most appropriate for my topic, the materiality of manuscripts. It is the historiated initial for the second section of the Psalm readings. The gold in the initial for Psalm 30 not only outlines the D but is also used for a extended halo for the Christ child which surrounds the full body. This follows the famous account in the Revelations of St Birgitta of Sweden where she reports that she saw the light during the birth of Christ emanating from the baby lying on the floor. ${ }^{53}$ The nuns copied the text of this vision into their prayer-books and included this detail in their illustrations. We have here an aspect of the Life of Christ coupled with a word illustration of the beginning of the Psalm Dominus illuminacio mea. In the golden halo radiating from the Christ child as word incarnate, the concept of illumination as enlightenment is translated through the use of gold leaf. This verse from the Psalm, which when used, for example, as the motto for the University of Oxford, serves as a formulation for the inspiration which all academics hope for, is used here by the nun as a theological concept to show why, after all, the materiality of manuscripts matters.

Notes on Contributor: Henrike Lähnemann holds the Chair of Medieval German Literature and Linguistics at the University of Oxford since 1 January 2015. Her current research focuses on late medieval devotional manuscripts and early print culture from Northern Germany. Her two most recent publications are Liturgie und Reform im Kloster Medingen (with Ulrike Hascher-Burger, 2013) and Mysticism and Devotion in Northern Germany (ed. with Elizabeth Andersen and Anne Simon, 2014).

Dear Claire, dear Birgit,

Many thanks for the work on the article which looks great! I have only a couple of typos (my apologies!), a couple of wrong hyphenations, a couple of missing italics, answers to the two queries and one request; I have all marked up in the attached pdf but since I had to do it on

53 Andersen, 'Das Kind sehen', p. 290. 
the move on a macbook air and am not sure how well these transport, I attach it to this email and repeat it for safety.

Many thanks for your help. I should be on a stable internet connection tonight in the hotel in Fribourg but only in the area of a proper computer et al once I am back in Oxford on Sunday. Yours, Henrike

Here goes:

p. 121 , footnote 1 , line 47 : bust --> medallion

p. 122 , footnote 3 , line 85 : insert semicolon after "2006)": 2006); charters

p. 122 , footnote 4, line 91 : change hyphenation from Hands-chriften to Hand-schriften

p. 126, line 255, query AQ1: ideally, move (Figure 3) up to line 248 behind Crucifixion

p. 130, line 451, query AQ2: please move (Figure 4) down two lines behind Psalm 1

p. 132, line 574: change hyphenation from Schle-ier to Schlei-er (or don't hyphenate)

p. 134, footnote 34, line 665: please put Verbum caro factum est et habitavit in nobis, et vidimus gloriam eius in italics

p. 134, footnote 34, line 666f: please put Godes sone is minsche worden in italics

p. 134 , footnote 35 , line 670 , Gesteliijk --> Gestelijk

p. 139, line 895: please insert (Figure 4) between "frame" and the full stop at the end of the paragraph

p. 141, line 978f: please put the titles Liturgie und Reform im Kloster Medingen and

Mysticism and Devotion in Northern Germany in italics

Finally my request: Would it at be possible to use the blank space on the last page to give a blow-up the detail from Figure 2 which I am discussing in the final paragraph? If yes, please insert between the end of the text and the ,Note on the Contributor' as extra image (Figure 6) a blow-up of the middle section of the right hand side of Figure 2, i.e. the lines of text 3-10 surrounding the gold letter. Caption: Fig. 6. Oxford, Bodleian Library, MS. Don. 2. 248, fol. 55r (Detail of Figure 2) 